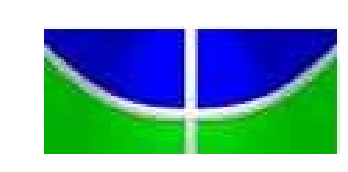

Universidade de Brasília

Centro de Excelência em Turismo

\title{
Turismo e Transporte Aéreo Regional no Brasil
}

Delfim da Costa Almeida 


\section{Turismo e Transporte Aéreo Regional no Brasil}

Aluno: Delfim da Costa Almeida

Orientadora: Deis Elucy Siqueira

Monografia apresentada ao Centro de Excelência em Turismo da Universidade de Brasília como requisito parcial para a obtenção do certificado de Especialista em Gestão de Negócios em Turismo. 
UNIVERSIDADE DE BRASÍLIA

Centro de Excelência em Turismo

Curso de Pós-Graduação em Gestão de Negócios em Turismo

\section{Turismo e Transporte Aéreo Regional no Brasil}

Delfim da Costa Almeida

Banca Examinadora

Prof. Dra. Deis Elucy Siqueira

Orientadora

Prof. MSc. Domingos Sávio Spezia

Examinador

Brasília - DF, maio de 2005 
Dedico esta monografia para os meus filhos Fábio, Danilo e Beatrice, para que o estudo e a pesquisa estejam impregnados no seu ser, sempre na busca do eterno aprender e da verdade. 
Quero agradecer profundamente ao meu amigo, professor Domingos Spezia, pelo incentivo e desafio para que eu fizesse este curso, a todos os professores e aos colegas com os quais convivi e muito aprendi ao longo desses meses e também se tornaram meus amigos. 


\section{Resumo}

O turismo virou um grande negócio no século $X X$ e aparece no século $X X I$ como sendo o maior gerador de empregos e de distribuição de renda. Os governos têm organizado essa atividade nos seus territórios e, no Brasil, grandes movimentos estão sendo feitos para reorganizar os potenciais pólos turísticos, comandados pelo Ministério do Turismo. O transporte aéreo deve funcionar como o grande facilitador desse processo, bem como na interiorização do turismo, neste país continente com 8,5 milhões de quilômetros quadrados de área. Dessa forma, a aviação regional deve ser fortalecida. Este trabalho apresenta alguns pontos de reflexão sobre o que pode ser feito para garantir uma aviação sustentável e suportar a integração nacional do turismo.

Palavras-chave: 1 . Turismo Regional 2 2. Transporte Aéreo 3 . Integração Nacional 


\begin{abstract}
The business of Tourism had a sharp increase in the 20th century and it appears in the 21st century as the number one job generator, as well as playing an important role as income distributor. Governments have been getting organized as to develop such activity within their territories and, in Brazil, great movements have been made towards the improvement of potential touristy areas, ruled by the Minister of Tourism. Air transportation should be the great facilitator of such process inside one that is an 8.5 million square kilometer continental country. Thus, inter-state aviation needs to be reinforced. The aim of this study is to present a few topics for reflection upon: what is possible to be done in order to prepare the country with supportive aviation, able to uphold the national integration of tourism.
\end{abstract}

Key words: 1 . Inter-state Tourism 2. Air Transportation 3. Nacional Integration. 


\section{Sumário}

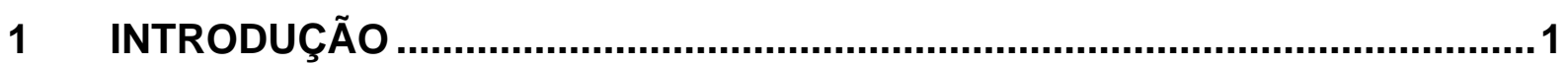

2 ORGANIZAÇÃO DO TRANSPORTE AÉREO NO BRASIL ............................. 4

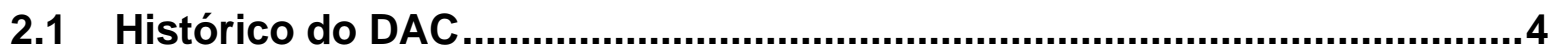

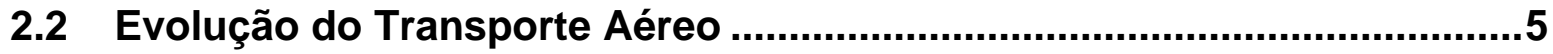

2.3 Turismo e Transporte Aéreo …...........................................................10

2.4 Crise no Setor da Aviação Civil .............................................................13

2.4.1 Congelamentos e Insuficiências Tarifárias ..........................................14

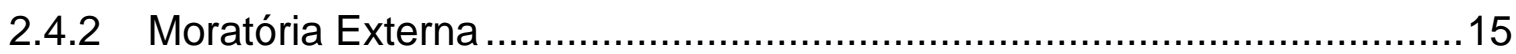

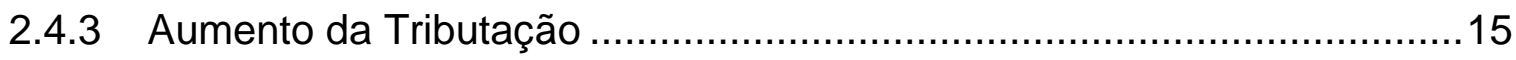

2.4.4 Combustível de Aviação (QAV) .......................................................16

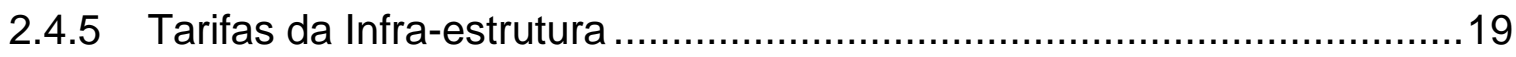

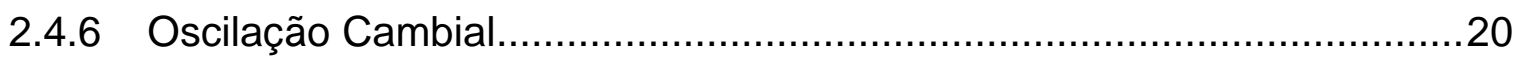

2.4.7 Sobretaxas nos Seguros de Aeronaves e as Taxas de Juros .................20

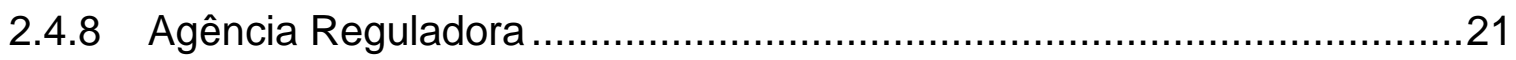

2.4.9 Eventos que acirraram a crise no setor ...........................................21

3 ANÁLISE DA PESQUISA DE CAMPO

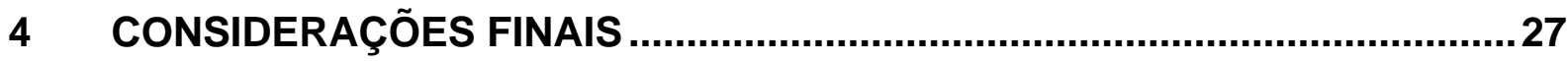

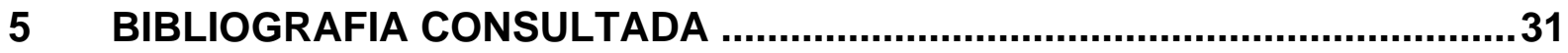




\section{Introdução}

Em todo o mundo os Governos têm participação direta ou indireta nas empresas aéreas de bandeira, por entenderem que o setor é estratégico na defesa dos interesses nacionais, gerador de divisas internacionais, fonte de integração do país e fomentador do desenvolvimento econômico.

Por que o Brasil parece não entender dessa forma? Será que foi uma boa medida os últimos Governos abandonarem as empresas à própria sorte, apesar de serem os responsáveis pela concessão das linhas e pelo equilíbrio econômico da atividade, conforme consta na Lei No. 7.565, de 19.12.86, o chamado Código Brasileiro de Aeronáutica - CBA? Nações com aspiração de participar da história mundial precisam ter aviação comercial forte, que funcione como instrumento de desenvolvimento, de integração e de difusão da cultura nacional.

O transporte aéreo é um dos setores mais dinâmicos da economia mundial. Ele cumpre importante papel estimulando as relações econômicas e o intercâmbio de pessoas e mercadorias (tanto dentro do país quanto com outros países) intra e entre as nações. O fenômeno da globalização vem provocando mudanças profundas nos padrões da demanda por mobilidade em escala mundial e alterando o comportamento de consumidores, aumentando continuamente os níveis de tráfego e levando a uma segmentação cada vez maior do transporte aéreo. Podem ser indicados como os dois vetores mais importantes da globalização: a tecnologia da informação e o avião!

No Brasil, país-continente, o transporte aéreo vem crescendo gradativamente com a economia desde os idos de 1927, mas a partir dos anos 90, o número de cidades servidas pelo transporte aéreo regular, decresceu de 400 cidades para cerca de apenas 100 cidades atendidas. Qual a razão desse fato? Qual é a posição do consumidor diante dessa realidade? Que medidas estão sendo tomadas pelas autoridades aeronáuticas para voltarmos a crescer em volume de cidades atendidas? Que papel a aviação geral e a aviação regional têm nesse contexto? São questionamentos que nos ocupam e preocupam, tendo em vista a atual situação das empresas aéreas regulares, onde são do conhecimento de todos as suas dificuldades em manter um serviço de qualidade, com segurança e com sustentabilidade econômica. 
Dessa forma, este trabalho se propõe a analisar e avaliar o setor de transporte aéreo regional no Brasil, assim entendido como sendo aquele que tem como meta desenvolver ligações a regiões do país cujo acesso ainda é considerado precário, favorecendo a integração nacional e a defesa do território, e contribuindo ainda para a redução das desigualdades regionais, através, dentre outras, do incremento da atividade turística local.

Neste contexto, a atividade turística local pode ser entendida como sendo o deslocamento de pessoas para desenvolver negócios, estudos, tratamentos de saúde, visitas e eventos familiares ou ainda para seu puro lazer, no interior do país (fora das capitais).

Como o transporte aéreo regional tem diminuído sua participação no mercado, ao longo dos anos, com aparente desprezo por parte das autoridades competentes, cada vez mais as pequenas e médias cidades são abandonadas pelas empresas aéreas que, na busca de maior rentabilidade das suas operações, buscam apenas os grandes centros urbanos a procura dos seus passageiros.

Dessa forma, o objetivo geral deste trabalho é demonstrar a importância do transporte aéreo para o desenvolvimento do turismo regional. Como objetivos específicos, são propostos os seguintes:

(i) elaborar um diagnóstico da situação atual do transporte aéreo brasileiro e

(ii) analisar a evolução do transporte aéreo no Brasil, da relação do turismo e o transporte aéreo e dos entraves da aviação civil no Brasil.

A metodologia utilizada para o desenvolvimento da pesquisa foi do tipo exploratória e bibliográfica. Assim, através de levantamento documental e revisão bibliográfica em livros, revistas e jornais, pesquisa de informações em sítios da internet e estudos de casos em congressos, seminários e fóruns, foi construída toda a base conceitual. Complementarmente, foi realizada uma pesquisa de campo a partir de questionário aplicado a onze executivos e freqüentes usuários do transporte aéreo. Além disso, também foi entrevistado o Tenente Brigadeiro Marcos Sfoggia, considerado pelo Setor, uma das maiores autoridades em aviação civil, ainda em exercício.

As fontes de pesquisa acessadas foram as próprias empresas aéreas; os órgãos do governo envolvidos, como o Ministério da Defesa, o Comando da Aeronáutica e o 
Departamento de Aviação Civil - DAC; as entidades de classe, como o Sindicato Nacional das Empresas Aeroviárias - SNEA, a Associação Brasileira das Empresas de Transporte Aéreo Regional - ABETAR. 


\section{Organização do Transporte Aéreo no Brasil}

O transporte aéreo no Brasil é regido pela Lei No. 7.565, de 19 de dezembro de 1986, mais conhecida como sendo o Código Brasileiro de Aeronáutica - CBA. Nesta lei está definido como sendo o Ministério da Aeronáutica, hoje Comando da Aeronáutica, a autoridade instituída para tratar de todos os assuntos correlatos, este, subordinado ao Ministro de Estado da Defesa. Contudo, está em tramitação no Congresso Nacional, um Projeto de Lei que atualiza a atual legislação. Neste Projeto, o órgão regulador do setor está definido como sendo a Agência Nacional de Aviação Civil - Anac, ainda a ser criada. Esse assunto é bastante polêmico, uma vez que diversas áreas do governo têm posições contrárias e outras favoráveis à criação dessa Agência, sendo que esses últimos alegam que a aviação comercial brasileira é o único setor da infra-estrutura que ainda não tem uma agência independente reguladora.

Enquanto isso não ocorre, o Departamento de Aviação Civil - DAC, órgão diretamente subordinado ao Comando da Aeronáutica, responde como órgão regulador e fiscalizador. Diante desse quadro de referência, o planejamento do transporte aéreo reveste-se de importância crucial. Trata-se, pois, de uma atividade a ser levada a sério e deve estar de acordo com os objetivos maiores do país: a integração, o crescimento e a segurança nacionais.

Desde 1986 o Instituto de Aviação Civil - IAC vem dando importante contribuição nesta área, exercendo papel de destaque no planejamento de aeroportos e no estudo do transporte aéreo em suas diversas dimensões.

\subsection{Histórico do DAC}

Em 22 de abril de 1931, foi criado, pelo Presidente Getúlio Vargas, o Departamento de Aviação Civil, subordinado ao, então, Ministério de Viação e Obras Públicas.

A preocupação governamental com a aviação civil remontava há alguns anos antes, mais precisamente, a 05 de janeiro de 1920, quando foi criada a Inspetoria Federal 
de Viação Marítima e Fluvial, acumulando atribuições referentes à navegação e à indústria aeronáuticas, à época, emergentes.

A década de trinta foi pródiga em movimentos intelectuais e políticos que propugnavam a doutrina do poder aéreo unificado e a criação de uma Força Aérea independente.

Assim é que, consubstanciando as aspirações dos pensadores e pioneiros de então, foi criado, em 20 de janeiro de 1941, também pelo Presidente Getúlio Vargas, o Ministério da Aeronáutica, incorporando todo o acervo material e humano das extintas Aviação Naval e Aviação Militar, bem como do Departamento de Aviação Civil.

Os diversos instrumentos legais, que ao longo desses mais de setenta anos de existência do departamento, se sucederam dando-lhe o arcabouço jurídico e institucional, foram gradativamente, consolidando a sua estrutura e as suas atribuições, as quais, hoje, podem ser sintetizadas nas que constam de seu regulamento: "O estudo, a orientação, o planejamento, a coordenação, o controle, o incentivo e o apoio às atividades da aviação civil, pública e privada".

Tais atribuições vieram a ser enriquecidas após a realização da $\mathrm{V}$ Conferência Nacional de Aviação Comercial - V CONAC, em 1991, e a subseqüente aprovação da política para os serviços de transporte aéreo comercial do Brasil, cujos objetivos visavam e visam a um fortalecimento da aviação civil brasileira e sua consolidação num cenário internacional globalizado e cada vez mais competitivo.

Os altos índices de eficiência operacional e de segurança de vôo de nossa aviação civil, em contexto mundial, são uma prova inconteste e eloqüente do acerto da doutrina pugnada pelos pioneiros dos anos trinta de concentrar, em um único ministério, a amplitude multidisciplinar da bivalência civil e militar dos assuntos aeronáuticos.

\subsection{Evolução do Transporte Aéreo}

A evolução da Política do Transporte Aéreo atravessou, basicamente, três fases bastantes características. 
É importante frisar que em todas estas fases esteve sempre presente na Política do Transporte Aéreo o critério da preservação da soberania e do mercado brasileiro.

A seguir, como vem evoluindo o Transporte Aéreo Brasileiro ao longo dos anos (SNEA - Sindicato Nacional das Empresas Aeroviárias):

\section{7}

O governo libera, à iniciativa privada, a exploração dos serviços de transporte aéreo. As primeiras concessões para exploração de linhas foram autorizadas para a empresa aérea brasileira VARIG e, em caráter precário, às empresas estrangeiras Condor Syndikat e Aéropostale. Trata-se do único caso registrado de autorização para exploração de tráfego de cabotagem, no Brasil, por empresa estrangeira.

A VARIG e a SINDICATO CONDOR (resultante da nacionalização da CONDOR SYNDIKAT) se organizam e se registram como empresas de aviação, e obtêm concessão para exploração de suas linhas pioneiras.

\section{$\underline{1940 / 50}$}

Essa fase estendeu-se pelas décadas de 40 e 50, e até o início da década de 60, e ao longo dela, mais de 20 empresas foram criadas, as quais concentraram as suas linhas principalmente nas rotas do litoral.

O excesso de oferta que se estabeleceu, em relação à demanda então existente, culminou por tornar anti-econômicos os vôos por elas realizados.

O mercado da época, de dimensões reduzidas, não foi suficiente para viabilizar o funcionamento de um número tão grande de empresas e todas elas se enfraqueceram, sendo que muitas faliram ou foram absorvidas por outras, ou se fundiram. A conseqüência foi uma redução nos níveis de segurança e de regularidade no serviço de transporte aéreo.

\section{0}

Na década de 60, a aviação comercial brasileira alcançava uma crise econômica de graves proporções, causada por diversos fatores, como: a baixa rentabilidade do transporte aéreo provocada pela concorrência excessiva; a necessidade de novos 
investimentos para a renovação da frota, visando à substituição das aeronaves do pós-guerra, cuja manutenção tornava-se difícil e cuja baixa disponibilidade prejudicava a regularidade do serviço; as alterações na política econômica do país, que retirou das empresas aéreas o benefício do uso do dólar preferencial para as importações, etc.

Para escaparem da crise, e poderem, talvez, sobreviver, as empresas aéreas, juntamente com o governo, reuniram-se para estudar uma mudança na política então reinante, de forma a garantir a continuidade dos serviços de transporte aéreo, mesmo que, caso necessário, o número de empresas tivesse que ser reduzido e o governo tivesse que exercer um controle mais rígido sobre elas.

Três dessas reuniões, denominadas Conferências Nacionais de Aviação Comercial (CONAC), foram realizadas na década de 60. A $1^{\mathrm{a}}$ em 1961, a $2^{\mathrm{a}}$ em 1963 e a $3^{\mathrm{a}}$ em 1968. As deliberações, conclusões e recomendações, a que se chegaram nessas conferências, conduziram a uma política de estímulo à fusão e associação de empresas, com o fim de reduzir o seu número a um máximo de duas na exploração do transporte internacional e três no transporte doméstico. Iniciava-se o regime de competição controlada em que o governo passou a intervir pesadamente nas decisões administrativas das empresas, seja na escolha de linhas, no reequipamento da frota, no estabelecimento do valor das passagens, etc.

Iniciou-se assim a segunda fase da evolução da política governamental para o setor da aviação civil, que se estendeu até a década de 80 , e foram adquiridos os primeiros aviões turbo-hélice e jatos da aviação civil brasileira.

\section{5}

Com a introdução de aeronaves mais modernas, e de maior porte, as empresas viram-se forçadas a modificar a sua rede de linhas, optando por servir apenas as cidades de maior expressão econômica, cujo mercado viabilizasse a prestação do serviço com o uso de aeronaves desse tipo. As pequenas cidades do interior, dotadas, normalmente, de um aeroporto precariamente equipado, cuja pista, em geral, não era pavimentada, e que no passado eram servidas por aeronaves de pequeno porte, passaram, simplesmente, a não mais dispor do serviço. Assim é que, 
de um total de 335 cidades servidas por linhas aéreas em 1958, somente 92 continuavam a dispor do serviço em 1975.

Atento ao problema, o então Ministério da Aeronáutica decidiu criar uma nova modalidade de empresa aérea, a empresa regional, para atender as cidades interioranas, dentro do conceito do novo sistema de transporte aéreo regional, que foi criado pelo Decreto N. ${ }^{0} 76.590$, de 11 de novembro de 1975 . No entanto, de conformidade com a política em vigor, de competição controlada, apenas cinco empresas foram criadas, devendo, cada uma delas, operar dentro de uma determinada região.

Assim, para operarem nas cinco regiões em que se dividiu o território nacional, foram criadas, em 1976, as empresas NORDESTE (Estados do NE, parte do MA, ES e grande parte de MG), RIO-SUL (Estados do Sul e RJ, parte do ES, faixa litorânea de São Paulo), TABA (Estados da Amazônia e partes Oeste do Pará e Norte do MT), TAM (MS, partes do MT e SP) e VOTEC (estados de Tocantins, Goiás e DF e parte do PA e MG e MT).

O novo sistema de transporte regional teve também, como objetivo, viabilizar a utilização, em maior escala, do avião BANDEIRANTE, lançado quatro anos antes pela EMBRAER, e que estava tendo grande aceitação para uso na aviação regional nos Estados Unidos da América.

\section{$\underline{1989}$}

Ao longo da década de 80, e mais especialmente, ao seu final, uma nova ordem política, econômica e social começou a se instalar, de uma maneira global, em quase todos os países do mundo. A marca mais importante da implantação dessa nova ordem foi, provavelmente, a derrubada do muro de Berlim, em novembro de 1989, que iniciou o esfacelamento do Socialismo, em especial da antiga União Soviética.

Essas mudanças filosóficas, marcadas pela predominância do pensamento liberal, levaram os governos, de uma maneira geral, a reduzirem o seu controle sobre a economia dos seus respectivos países, permitindo que a mesma fosse conduzida pelas livres forças do mercado. 
Embora, em 1986, tivesse-se realizada a IV CONAC, sem trazer nenhuma modificação substancial à política vigente, também no Brasil, mudanças começaram a ser introduzidas, sob a influência daquele pensamento. O governo, gradualmente, a partir de então, passou a abandonar o regime de indexação da economia e de fixação de preços. Em harmonia com essa nova política econômica do governo, o então Ministério da Aeronáutica, por intermédio do DAC, definiu-se, a partir de 1989, por uma política de flexibilização tarifária. Com base nessa política abandonou o regime de fixação do preço das passagens aéreas, substituindo-o pelo estabelecimento de uma faixa de variação do preço em torno de um valor fixado pelo DAC, correspondente à tarifa básica. Foi o início da $3^{a}$ fase da evolução da política para o transporte aéreo.

Buscando aprimorar essa política e torná-la ainda mais consentânea com a do Governo Federal, o então Ministério da Aeronáutica fez realizar, em novembro de 1991, a V Conferência Nacional de Aviação Comercial (V CONAC), com a participação de todos os segmentos da indústria do transporte aéreo, visando à definição clara de uma política sintonizada com as tendências liberalizantes observadas em diversos países do mundo.

Com base nos resultados dessa conferência, o Ministério estabeleceu diretrizes para orientar a ação do seu órgão regulador, o DAC, no sentido de proceder a uma redução gradual e progressiva da regulamentação existente.

Em conseqüência dessa nova política e das diretrizes dela decorrentes, foi implementado o sistema de liberação monitorada das tarifas aéreas domésticas; foi aberto o mercado doméstico para a entrada de novas empresas, tanto de transporte regular quanto de transporte não regular, incluindo regionais e cargueiras, as quais passaram de 17, em 1991, para um total de 41; foi suprimida a delimitação de áreas para exploração do transporte regional e a exclusividade desfrutada, dentro das mesmas, por algumas empresas; flexibilizaram-se os parâmetros para a concessão de linhas; foram designadas novas empresas nacionais para explorar o transporte aéreo internacional; foi admitida a criação e o licenciamento de um novo tipo de empresas, destinadas à exploração do transporte aéreo não regular de cargas e passageiros, na modalidade de "charter"; e foi, enfim, como decorrência de todas 
essas medidas, aumentada a oferta ao usuário, que passou de $22.560 .000 \mathrm{Ass} / \mathrm{Km}$ em 1991, para cerca de 32.000.000.

A nova modalidade de serviço aéreo, não regular, introduzido pelo DAC em 1989, e aceita pela V CONAC em 1991, foi, juntamente com a introdução das bandas tarifárias, um dos passos mais importantes em direção à flexibilização da regulamentação do transporte aéreo. Já em 1990, seis empresas passaram a explorar o transporte aéreo não regular, e o seu número continuou crescendo, chegando a 23 em 1995. Entretanto, em 1998, somente 20 delas continuavam registradas e autorizadas a funcionar.

A abertura para a exploração dessa nova modalidade de serviço despertou o interesse de inúmeros empresários com capital disponível e que procuravam um setor onde pudessem investi-lo e obter um retorno satisfatório.

Desafortunadamente, porém, o mercado disponível para a exploração desse serviço foi superestimado e não comportou tanta oferta, e hoje, das 20 empresas existentes, apenas 08 continuam operando, precariamente. Entretanto, apesar dos resultados insatisfatórios obtidos pelas empresas não regulares, o DAC não considera frustrada sua iniciativa de buscar novas formas de desenvolvimento do transporte aéreo, e pretende manter seus esforços para viabilizar o transporte aéreo não regular, sem se descuidar, obviamente, das demais modalidades, sejam elas as tradicionais e consagradas, ou novas modalidades que se criem como decorrência do desenvolvimento da indústria do transporte aéreo.

\subsection{Turismo e Transporte Aéreo}

Deve-se levar em consideração que o turismo é um fenômeno universal e é o responsável por conectar todas as partes do sistema global, fazendo com que os indivíduos sintam-se como participantes de um mundo globalizado, de um todo. Paralelamente, cresce no povo, sua consciência de fortalecimento de identidade cultural, divulgando suas raízes, seus costumes e sua forma de vida. Cada vez mais é entendida pela civilização moderna a necessidade de se viajar, de fazer turismo, na sua integração com outros povos para conhecimento e divulgação simultaneamente. 
Nesse contexto, o transporte aéreo é particularmente imprescindível. O que mais conta na civilização moderna é a rapidez com que as coisas acontecem. Há necessidade de se fazer um pouco de tudo, no menor espaço de tempo possível. Essa afirmação é um desafio constante nos técnicos da indústria de aviação mundial. Há que se fazer aeronaves cada vez mais rápidas, para que permitam que o viajante vá e volte o mais rápido possível. A tecnologia progride, os custos aumentam e o transporte aéreo fica cada vez mais sofisticado.

Os custos das empresas aéreas não param de crescer. É uma atividade da economia que tem como obrigação básica o uso de altíssima tecnologia, de mão de obra altamente especializada. O consumo de combustível responde por mais de $25 \%$ da sua planilha de custos. É tremendamente suscetível a qualquer oscilação do mercado internacional. No Brasil, temos ainda o efeito de sermos um país em desenvolvimento, onde o crédito internacional é muito mais dificultado, seja pelas garantias a serem oferecidas, seja pela política cambial exercida, que quase sempre deixa as organizações financeiras do exterior com desconfiança a nosso respeito. Ser empresário do transporte aéreo no Brasil, mais que uma vocação, deve ser indivíduo talhado para o empreendedorismo.

Diversas empresas nasceram e morreram no Brasil. O setor vive de crises. Muitas foram as empresas de vida curta.

"A aviação comercial brasileira e o turismo interno viveram época de vacas gordas no início dos anos 90. Os pacotes de viagem para o nordeste do país e para o exterior foram vendidos em larga escala e nunca o brasileiro viajou tanto de avião. Surgiram no país novas empresas aéreas, a maioria tipicamente charter. Porém, tiveram vida curta." Revista Flap Internacional, no. 389, pg. 67.

No momento, a maior expectativa da indústria do transporte aéreo é com relação a estabilidade da economia, tendo em vista a alta correlação existente entre a demanda e a atividade econômica. O DAC tem estudos que mostram o crescimento do número de passageiros embarcados no Brasil sempre sendo o dobro do aumento do PIB.

"Pensar em atividade turística é pensar em geração de emprego, distribuição de renda, fomento de diversos segmentos de economia, em cifras que aumentam a cada ano. Por isso, em todo o mundo, os governos voltam seus olhos para o setor de turismo, onde encontram 
abundância de oportunidades para impulsionar o crescimento econômico e o desenvolvimento social. Com essa compreensão, o Brasil também investe no turismo, valorizando as iniciativas e investimentos no setor." Deputado José Militão, Presidente da Comissão de Turismo e Desporto da Câmara dos Deputados.

"Vejo o setor de turismo como uma das mais relevantes ferramentas de promoção do desenvolvimento do País. Além de gerar riquezas e empregos formais, permite o desdobramento das cadeias produtivas informais e a inserção de seus atores no contexto da cidadania e dignidade. Somado a isso, o turismo, proporciona lazer, aproxima os povos, difunde a cultura da sua gente e promove a paz entre as nações. Nesse contexto, o Brasil é privilegiado, pois possui paisagens belíssimas, um clima maravilhoso e um povo hospitaleiro. É dessa forma que acredito no turismo." Deputado Reinaldo Betão, autor do requerimento da Sessão Solene da Câmara dos Deputados, do dia 28 de setembro de 2004, em homenagem ao Dia Mundial do Turismo (27 de setembro).

O Turismo é a maior fonte geradora de receita dos paises que pensam em um desenvolvimento sustentável, usuário de grande contingente de mão de obra e, portanto, gerador de emprego, e ainda é uma indústria considerada não poluente. É dos maiores divulgadores da cultura de um povo e não pode ser "consumido" sem que o seu usuário visite o local. Não se pode fazer turismo via internet, através de livros e revistas, mas apenas e tão somente, visitando-se o local. Por essa razão, a correlação de turismo, viagem e transporte aéreo é fundamental e não se pode dissociar um do outro. Não há como falar em turismo sem falar em transporte.

O Ministro de Estado do Turismo, Sr. Walfrido dos Mares Guia, no Fórum Mundial de Turismo para Paz e Desenvolvimento Sustentável, ocorrido em Salvador - BA, de 01 a 06 de dezembro de 2004, divulgou o movimento em prol de uma causa: Desenvolver o turismo, promovendo:

1- Condições para a Paz;

2- Desenvolvimento Social;

3- Diversidade Cultural;

4- Preservação da Biodiversidade; e

5- Desenvolvimento Econômico.

De acordo com os anais do fórum, pode-se destacar:

"O turismo é uma das principais atividades econômicas do século 21, movimentando 3,5 trilhões de dólares em 2003, o que equivale a 10\% do PIB mundial. Em 2002, 715 milhões de pessoas viajaram de um país para outro, movimentando a fantástica cifra de 474 bilhões de dólares. 
Hoje, o turismo é responsável por um em cada dez postos de trabalho no mundo e, como indústria global, tem contribuído para o bem-estar das populações e para o aprendizado humano, principalmente a partir de intercâmbios culturais, tornando-se uma valiosa ferramenta de manutenção da paz.

Mais do que nunca, é necessário descobrir possibilidades de crescimento econômico que levem em conta uma idéia abrangente de sustentabilidade, incluindo e valorizando a dimensão ecológica e a conservação do meio ambiente, e, ao mesmo tempo, os aspectos sociais e culturais do desenvolvimento.

O turismo representa uma grande oportunidade nessa direção, e exemplos de boas práticas já estão disponíveis em inúmeros países, havendo situações concretas de atuação decisiva sobre a diversidade cultural e biológica, por exemplo. É tempo de avaliar e disseminar essas lições aprendidas, estabelecer mecanismos para evitar a repetição de enfoques ultrapassados, e garantir que os modelos de sustentabilidade do turismo sejam usados em escala mundial."

O ministro tem como metas da sua pasta, dentro do Programa Nacional do Turismo:

- Criar 1.200.000 novos postos de trabalho;

- Chegar a 9 milhões de turistas estrangeiros entrando no país;

- Gerar 8 bilhões de dólares em divisas;

- Aumentar para 65 milhões os desembarques domésticos;

- Desenvolver pelo menos três produtos turísticos por Estado e DF.

Pode-se constatar que das cinco metas, quatro delas estão diretamente ligadas ao transporte aéreo, neste país continente com 8,5 milhões de quilômetros quadrados de extensão.

\subsection{Crise no Setor da Aviação Civil}

Os últimos dezoito anos (1986/2004) caracterizaram-se por fatores adversos externos que abalaram profundamente as companhias aéreas brasileiras, levandoas a operar com rentabilidade negativa na quase totalidade do período, não obstante a implementação, pelas empresas, de radicais programas de redução e contenção de custos e adoção de novas tecnologias gerenciais. É ilustrativo, por exemplo, a violenta redução do quadro de pessoal da VARIG que, em 1991, somava 28.092 empregados e, dez anos depois (em 2001) estava reduzido para 16.993 empregados.

Esses fatores externos adversos resultaram, ao longo daqueles dezoito anos, num elevado endividamento das companhias por perdas acumuladas em sucessivos 
exercícios, tendo o patrimônio líquido das mesmas registrado valores negativos já a partir do ano 2.000 .

Especialistas do setor e, de maneira geral, todos aqueles que acompanharam a economia brasileira nos últimos anos, identificam como fatores principais do endividamento das companhias - mas não exclusivamente: a moratória externa; os sucessivos planos econômicos; os congelamentos tarifários por longos períodos, sem reposição de custos fixos e variáveis; a inflação crônica; a insuficiência tarifária; o excesso de tributação sobre a atividade; os preços dos combustíveis de aviação; a majoração real de tarifas aeroportuárias e aeronáuticas; a criação de adicionais tarifários; as bruscas variações cambiais; as ineficiências de infra-estrutura; o "riscoBrasil"; os acréscimos de juros nos financiamentos para capital de giro; os contínuos aumentos de tributação, inclusive os de repercussão sobre a importação de aeronaves e peças de reposição; os acréscimos nos custos de seguros de aeronaves decorrentes de crises internacionais; a guerra do Golfo; os atentados de 11 de setembro de 2001; a invasão do Iraque; os insuportáveis aumentos nos níveis das taxas de juros, que contraem a demanda por transporte aéreo e a ausência de uma agência reguladora do setor.

\subsubsection{Congelamentos e Insuficiências Tarifárias}

Os congelamentos tarifários estabelecidos pelos inúmeros Planos Econômicos, bem como as insuficiências tarifárias registradas ao longo dos anos foram responsáveis, entre todos os outros fatores externos negativos, pelos piores danos às companhias aéreas.

É oportuno ressaltar que a política de realidade tarifária conduzida e aplicada com sucesso pelo Ministério da Aeronáutica ate 15 de março de 1985 foi anulada pelas autoridades econômicas, como instrumento de contenção da inflação. Com efeito, a partir daquela data, a fixação, o reajuste e a revisão das tarifas públicas passaram a ser controlada pelo Ministério da Fazenda, segundo os parâmetros gerais estabelecido para os demais preços da economia (Decreto $\mathrm{n}^{\circ}$ 91.145, de 15 de março de 1985 , art. $5^{\circ}$ ). Todavia, no que se refere às tarifas aéreas, passaram as mesmas a serem reajustadas após e em níveis muito inferiores aos aumentos dos custos dos serviços das empresas, inclusive com violação frontal das cláusulas 
contratuais que asseguravam o equilíbrio econômico-financeiro dos respectivos contratos de concessão.

Nesse contexto, levantamentos realizados pelas autoridades aeronáuticas e pelas companhias aéreas, destinados a quantificar as perdas decorrentes da "prática de insuficiência tarifária" no transporte aéreo doméstico comprovaram que, só entre os anos de 1985 e 1991, o conjunto das companhias aéreas sofreu perdas equivalentes a U\$ 2,4 bilhões, que tiveram de ser financiadas mediante empréstimos realizados com taxas de juros extorsivas.

\subsubsection{Moratória Externa}

De outro lado, a moratória externa declarada pelo Brasil em 1986 resultou num brutal acréscimo de custos para as companhias aéreas brasileiras, em decorrência não só do imediato aumento nos preços internacionais das aeronaves, suas partes. peças e componentes, mas, sobretudo nas taxas de juros cobradas nos respectivos arrendamentos operacionais e financeiros e serviços de assistência técnica.

No caso da VARIG, a moratória impediu a empresa de concluir as negociações que vinha realizando nos Estados Unidos para a aquisição de cinco "Jumbos” B 747-300. A solução encontrada pelas nossas autoridades econômicas foi a autorização para a contratação de operação de crédito externo com instituições bancárias japonesas, na moeda daquele país. A subseqüente valorização do "iene" frente ao dólar norteamericano resultou para a empresa na duplicação do montante do empréstimo tomado, inviabilizando o projeto de amortização. Em vista disto, as aeronaves foram desativadas e devolvidas no curso da reestruturação empresarial realizada em 1999, ocasião na qual ainda restou um saldo a pagar na ordem de U\$ 250 milhões.

\subsubsection{Aumento da Tributação}

De igual modo, o aumento da tributação implicou não só na perda de competitividade das empresas brasileiras perante suas congêneres no transporte aéreo internacional, como resultou num aumento substancial de custos no transporte aéreo doméstico, insuscetível de ser repassado aos usuários da aviação civil, em razão da forte contração da demanda que se seguiu a 1987, decorrente de perdas reais de renda da população provocadas pelas diversas políticas econômicas implementadas no período, além de medidas de desregulamentação que 
provocaram "guerras tarifárias" e aumento de oferta de assentos, com diminuição crescente do "load factor" setorial.

Estudos comparativos refletindo os percentuais de carga tributária incidente sobre a indústria de transporte aéreo realizados no ano 2000, indicavam a situação demonstrada no quadro 1 , a seguir:

Quadro 1: Carga Tributária sobre as vendas

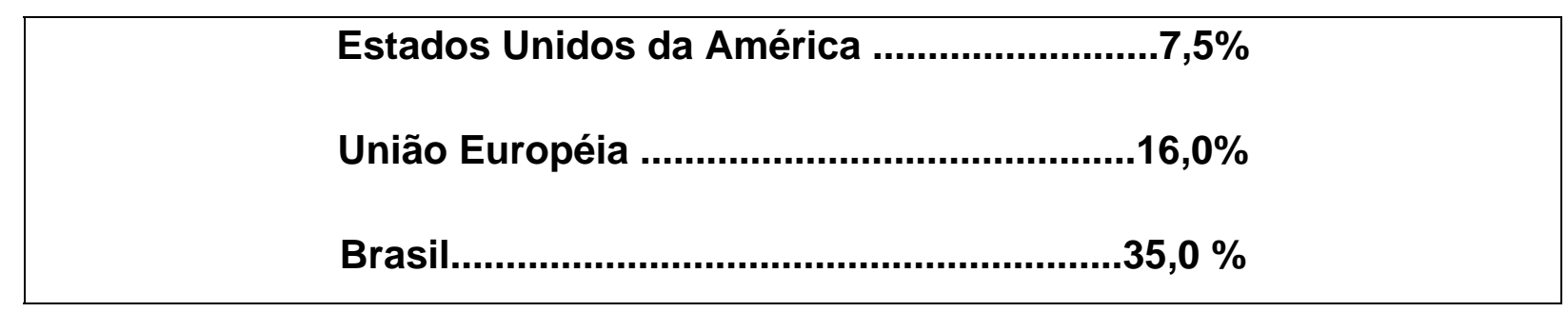

Fonte: SNEA (2000)

A participação da carga tributária no valor das passagens aéreas em dezembro de 2.003 era a seguinte:

Quadro 2: Carga Tributária sobre as receitas e custos

Tributos sobre receitas. $22 \%$

Tributos sobre custos. $.13 \%$

Fonte: SNEA (2003)

\subsubsection{Combustível de Aviação (QAV)}

Da mesma forma, a aviação comercial brasileira vem sendo gravemente penalizada pela política de preços praticada no seu principal insumo, o querosene de aviação (QAV), que responde hoje por cerca de $23 \%$ de seus custos. Na fixação do preço e nos reajustes do QAV vem sendo praticada uma política discriminatória contra a 
aviação civil, tornando o QAV consumido pelas companhias aéreas cada vez mais caro em relação aos demais derivados do petróleo, como comprovam os dados abaixo:

\section{Quadro 3: Aumentos Cumulativos de Preços - Período Jan/99 a Dez/04}

\begin{tabular}{|l|l|}
\hline Produto & variação \% por produto \\
\hline gasolina automotiva & 266,70 \\
\hline óleo diesel & 427,30 \\
\hline querosene de aviação (QAV) & 906,00 \\
\hline GLP & 441,30 \\
\hline
\end{tabular}

Fonte: SNEA

As discrepâncias anteriormente mencionadas tornam-se mais significativas quando comparada a variação dos aumentos nos preços do QAV com a variação de outros indicadores macroeconômicos, como mostra o Quadro abaixo:

\section{Quadro 4: Comparação da Evolução do Preço do QAV/Indicadores}

\begin{tabular}{|l|l|}
\hline Indicador & Variação \% jan/99 a dez/04 \\
\hline QAV* & 906,0 \\
\hline DÓLAR & 131,2 \\
\hline IGP-DI & 122,0 \\
\hline IGP-M & 123,2 \\
\hline INPC & 67,9 \\
\hline IPCA & 64,5 \\
\hline
\end{tabular}

Fonte: DAC, relatórios operacionais

Em conseqüência dessa política, o item QAV, nos últimos anos, aumentou despropositadamente sua participação no percentual de custos da indústria, como pode ser constatado no quadro a seguir: 
Quadro 5: Evolução da Participação do QAV na Planilha Consolidada da Indústria Doméstica

\begin{tabular}{|l|l|l|l|l|}
\hline Ano & $\mathbf{1 9 9 9}$ & $\mathbf{2 0 0 0}$ & $\mathbf{2 0 0 1}$ & $\mathbf{2 0 0 2}^{*}$ \\
\hline percentual & $13,63 \%$ & $18,64 \%$ & $21,43 \%$ & $23,19 \%$ \\
\hline
\end{tabular}

Fonte: DAC, relatórios operacionais

Não fosse somente isto, o QAV fornecido no Brasil é um dos mais caros do mundo, inclusive com preços em dólares superiores aos praticados em países altamente dependentes de petróleo, com é o caso do Estados Unidos da América. O Quadro abaixo mostra a evolução do prelo do QAV em outros países, mostrando a desvantagem competitiva entre as empresas brasileiras e suas congêneres estrangeiras, como podem ser observadas:

Quadro 6: Período jan/00 a jun/02 (US\$ cents/litro)

\begin{tabular}{|l|l|l|l|l|}
\hline Local & Segmento & Jan 00 & Jun 02 & $\begin{array}{l}\text { Var em US\$ } \\
\text { (\%) }\end{array}$ \\
\hline Buenos Aires & Internacional & 21,50 & 20,66 & $-3,9$ \\
\hline Londres & Internacional & 22,19 & 19,73 & $-11,1$ \\
\hline Paris & Internacional & 23,56 & 20,74 & $-12,0$ \\
\hline Montevideo & internacional & 26,29 & 21,08 & $-19,80$ \\
\hline EUA & dom + intern & 19,05 & 18,02 & $-5,4$ \\
\hline EUA & Doméstico & 18,45 & 17,65 & $-4,3$ \\
\hline EUA & internacional & 20,77 & 18,96 & $-8,7$ \\
\hline Brasil & dom + intern & $\mathbf{2 1 , 5 4}$ & $\mathbf{2 6 , 3}$ & $\mathbf{2 2 , 1}$ \\
\hline Brasil & Doméstico & $\mathbf{2 1 , 0 7}$ & $\mathbf{3 0 , 4 1}$ & $\mathbf{4 4 , 3}$ \\
\hline Brasil & internacional & $\mathbf{2 2 , 9 5}$ & $\mathbf{2 2 , 8 5}$ & $\mathbf{- 0 , 4}$ \\
\hline
\end{tabular}

Fonte: DAC (variação cambial no período: 50,47\%)

Conclui-se, portanto, que o preço do QAV vem sendo reajustado a taxas superiores a todos os demais combustíveis disponibilizados no País e, quando comparado à evolução dos demais preços da economia, situa-se indecorosamente acima, produzindo efeito de confisco. Nesse contexto, também é oportuno lembrar que o 
preço do QAV é inelástico, ou seja, as companhias aéreas terão de continuar a consumi-lo, qualquer que seja o seu valor, pela razão de que não há como substituílo. Além disto, temos um único fornecedor nacional, que abarca $97 \%$ do mercado brasileiro de QAV, a estatal federal monopolista PETROBRAS. Note-se, também, que o QAV tem pequena participação no volume total de combustíveis comercializados no País (cerca de 5\%), assim como na produção de derivados (próximo a 4\%), conforme informações que podem ser colhidas na Agência Nacional de Petróleo (ANP).

\subsubsection{Tarifas da Infra-estrutura}

Com a promulgação da Lei no 7.920, em 12 de dezembro de 1989, houve um agravamento na crise das companhias aéreas, provocado pela criação de um adicional de $50 \%$ sobre os valores das tarifas aeroportuárias (embarque, pouso, armazenagem e capatazia), bem como sobre as tarifas aeronáuticas de uso dos auxílios à navegação aérea e das comunicações (em rota e em área terminal). Posteriormente, piorando ainda mais a situação, a Lei $n^{\circ} 9.825$, de 23 de agosto de 1999, destinou parcela da tarifa de embarque internacional, incluindo o seu correspondente adicional tarifário, à amortização da dívida pública mobiliária federal, com o que restaram promovidos aumentos reais nas demais tarifas aeroportuárias para compensar a perda de receita advinda da redestinação da parcela da tarifa de embarque.

É possível afirmar que os valores das tarifas aeroportuárias e aeronáuticas praticados no Brasil estão seguramente entre os mais altos do mundo. Levantamento publicado em 2.002 mostra, por exemplo, que o Aeroporto Internacional de São Paulo é o terceiro mais caro do mundo, atrás apenas dos aeroportos de Osaka e Tóquio, dentro do universo de mais de 50 aeroportos internacionais (Fonte: "Review of Airport Charges 2.001", Transport Research Laboratory ("TRL") em Annual Report 2001/2002, Hong Kong International Airport).

Observe-se, ainda, que valores das tarifas aeroportuárias e aeronáuticas, tal qual ocorre com o QAV, também são inelásticos, de vez que as companhias aéreas terão de continuar a utilizar os aeroportos e os sistemas de controle de tráfego aéreo nas suas operações, qualquer que sejam os seus valores, porque também aqui não há como substituí-los. Além disto, mais de $97 \%$ das operações em infra-estrutura 
aeroportuária são realizadas em aeroportos administrados pela monopolista "de fato" INFRAERO e 100\% das operações de navegação aérea em rota são controladas pelo DECEA, órgão do Comando da Aeronáutica, exercendo monopólio de fato da União.

\subsubsection{Oscilação Cambial}

Os últimos anos podem ser caracterizados como de forte oscilação da moeda brasileira frente ao dólar, sobretudo em 1999 e em 2.002. Em ambos os casos, os efeitos sobre a economia das empresas aéreas brasileiras foram extremamente graves. Em 2.002, as empresas brasileiras, por já estarem em situação delicada em decorrência da política cambial adotada em 1999, foram penalizadas simultaneamente com aumentos nos preços dos combustíveis produzidos pela PETROBRÁS e pelas condições desfavoráveis da economia nacional que se seguiram à desvalorização do real. A diminuição do ritmo de expansão da atividade econômica e o seu posterior encolhimento afetaram a demanda por transporte aéreo. A volatilidade constante da nossa moeda afetou negativamente o caixa das empresas em face da impossibilidade de promover-se ajustes nas tarifas aéreas. Demais disto, a retração dos serviços internacionais operados a partir do Brasil afetou o tráfego de passageiros-km transportados nas linhas internacionais. No caso da VARIG, a nossa maior operadora de linhas internacionais, a crise cambial de 1999 registrou queda de 15\% no tráfego de passageiros-km transportados.

É preciso entender-se que as oscilações cambiais afetam profundamente o desempenho das companhias aéreas, seja pelo lado da receita ou da despesa, tendo em vista que muitos dos insumos básicos para as atividades do setor são atrelados à moeda norte-americana, tais como o leasing, os seguros e a manutenção de aeronaves, o combustível, os suprimentos, o treinamento de pessoal, os serviços técnicos, os sistemas de reservas de passagens, etc.

\subsubsection{Sobretaxas nos Seguros de Aeronaves e as Taxas de Juros}

É oportuno destacar dentro desse quadro geral de crise, que a fragilidade da economia brasileira e o chamado risco-Brasil foram e são responsáveis pelos altos prêmios de seguros cobrados às companhias aéreas brasileiras, muito superiores aos pagos por empresas de outros países, embora o Brasil possua um alto índice de 
desempenho em segurança de vôos, semelhante aos dos EUA e do Canadá. Tal circunstância ocorre quando da aquisição de aeronaves no exterior, suas peças, partes e componentes: de regra, as empresas brasileiras de transporte aéreo pagam juros maiores e dispõem de menores prazos de financiamento do que suas congêneres estrangeiras. Juros mais altos também se aplicam às empresas brasileiras quando tomam recursos de empréstimos para financiar capital de giro.

\subsubsection{Agência Reguladora}

O setor de aviação comercial e de infra-estrutura aeroportuária e aeronáutica é o único setor infra-estrutural e de prestação de serviços públicos não contemplados com uma agência reguladora. O exercício da função reguladora setorial é detida pelo Departamento de Aviação Civil, órgão integrante da estrutura do Comando da Aeronáutica (ex - Ministério da Aeronáutica). Esse tratamento diferenciado não é isonômico e vem acarretando ao longo dos últimos anos o crescente isolamento do setor, com comprometimento da sua eficiência, sobretudo em decorrência da incompatibilidade entre as diretrizes da política de aviação civil formulada no âmbito do Conselho Nacional de Aviação Civil - CONAC e a regulação econômica editada pelo Departamento de Aviação Civil - DAC.

Demais disto, os processos decisórios do DAC não são transparentes, por que não sujeitos a qualquer controle social, como deve ocorrer com órgãos ou agências com poder regulatório de atividades econômicas.

\subsubsection{Eventos que acirraram a crise no setor}

A Guerra do Golfo (1991) e a crise que a antecedeu causaram à aviação comercial mundial (serviços regulares) prejuízos da ordem de US $\$ 20,4$ bilhões, incorridos nos exercícios de 1990 a 1994, com reflexos extremamente negativos sobre as companhias aéreas brasileiras, principalmente sobre a VARIG, nossa maior operadora.

Da mesma forma, os atentados de 11 de setembro de 2001 acarretaram prejuízos à indústria mundial de aviação comercial de mais de US\$25,2 bilhões nos anos de 2.001 a 2003, também com conseqüências devastadoras para a VARIG e as demais companhias aéreas brasileiras que exploram tráfego internacional. 
Em razão do caráter reconhecidamente estratégico do setor de aviação comercial regular, os países desenvolvidos perante as conseqüências dos atentados de 11 de setembro de 2001, adotaram providências imediatas de socorro financeiro às suas empresas nacionais.

Nos Estados Unidos da América, o Congresso autorizou, onze dias depois dos atentados:

- US\$ 15 bilhões de ajuda emergencial às suas empresas aéreas, dos quais US\$ 5 bilhões em subvenções a fundo perdido e US\$ 10 bilhões em empréstimos com taxas de juros negativas;

- subsídios para a indústria;

- garantias para empréstimos privado;

- $\quad$ suspensão de tributos;

- modificação na legislação dos custos de infra-estrutura e segurança;

- participação na cobertura para seguros;

- (apesar da ajuda financeira, o mercado reduziu 400.000 postos de trabalho, sendo 100.000 diretos).

No Canadá:

- o Governo canadense liberou US\$160 milhões de ajuda financeira às suas empresas;

- as freqüências de vôo foram reduzidas em 20\%;

Na Europa:

- o Governo inglês recebeu aprovação da comunidade européia para conceder 10 milhões de libras de ajuda financeira para empresas inglesas;

- a Comissão Européia liberou subsídios para cobrir prejuízos com vôos cancelados e redução do tráfego aéreo e para os investimentos necessários para aumentar a segurança de vôos e os seguros das aeronaves e passageiros; 
- a França liberou financiamentos de US\$ 280 milhões para suas empresas, a serem pagos mediante taxa incluída nos bilhetes de passagens aéreas;

- a empresa suíça "Crossair", subsidiária da falida "Swissair", recebeu os ativos desta, retomando as atividades e sem qualquer responsabilidade pelo passivo da segunda, integralmente assumido pelo governo, além de ter recebido dos eleitores do Cantão de Zurique (sensíveis ao caráter estratégico da sua empresa nacional), a subscrição da importância de 300 milhões de francos suíços para integrar o capital da referida empresa.

Na Ásia e Oceania:

- O Governo neo-zelandês pagou US\$ 360 milhões para resgatar a Air New Zealand, que sofreu problemas financeiros;

- A Malaysia Airlines beneficiou-se de um plano de reestruturação governamental, com a criação de uma holding e assunção de seu passivo pelo governo;

A diferença substancial entre os impactos desses eventos nas companhias aéreas é que, no que respeita às estrangeiras, os respectivos governos nacionais promoveram forte e imediata ajuda financeira às suas companhias aéreas, minorando os efeitos devastadores daqueles eventos, enquanto que no Brasil, ao longo do período de ajustamento das empresas estrangeiras às crises referidas, as empresas brasileiras foram penalizadas com aumentos substanciais:

(i) nos tributos incidentes sobre suas atividades;

(ii) nas tarifas aeroportuárias e aeronáuticas aplicáveis às suas operações;

(iii) no preço do combustível consumido pelas suas aeronaves;

(iv) nas taxas de juros que financiaram as suas necessidades de capital de giro e, finalmente;

(v) nos prêmios de seguros de suas aeronaves. 


\section{Análise da pesquisa de campo}

A pesquisa de campo foi realizada no primeiro trimestre de 2005. Os questionários foram encaminhados, via internet, para vinte executivos que utilizam com regularidade o transporte aéreo, sendo a seleção feita em relação ao ramo de atividade e freqüência com que utilizam. Dos vinte questionários encaminhados, apenas dez puderam ser validados.

Para esses executivos, foram feitas as seguintes perguntas:

1- Você entende que o transporte aéreo contribui para o desenvolvimento do turismo no Brasil? Por quê?

2- Sabendo-se que, em 1990, o Brasil detinha 65\% do tráfego aéreo entre o Brasil e os EUA e, após a liberação efetuada pelo Governo Collor, permitindo que mais empresas norte-americanas voassem para o Brasil, ficamos hoje com menos de $35 \%$ desse mercado, permitindo que houvesse redução na entrada de divisas no país da ordem de quase USD 1 bilhão. Você é a favor de liberar o transporte aéreo para empresas estrangeiras ou entende que 0 governo deve controlar essa demanda?

3- Você entende que o transporte aéreo no Brasil devia seguir o modelo europeu, sendo propriedade do Estado, ou devia seguir o modelo americano, sendo propriedade privada?

4- Sabendo-se que mesmo nos EUA, não é permitido que estrangeiros sejam proprietários de empresas aéreas, você aceita o percentual de 20\% (limite de participação estrangeira nas empresas aéreas brasileiras), ou gostaria de propor outro percentual?

Analisando as respostas do questionário, conforme pode ser visto no anexo I, fica constatado que todos entendem que o Brasil precisa de transporte aéreo regional para o desenvolvimento do nosso turismo interno. Como cita o jornalista Gilberto Amaral: "Se não existissem as companhias aéreas, não haveria turismo no Brasil" e 
"as viagens terrestres são penosas e cansativas". Já o Engenheiro Gilson Machado, além de lamentar "o exorbitante preço das passagens", cita que " ... o turismo aéreo nacional sobrevive de uma forma tímida ..."

A grande maioria dos entrevistados entende que deve haver liberação do transporte aéreo para empresas brasileiras mas que, a Autoridade Aeronáutica, deve dar apoio para essas empresas nacionais. O Sr. Carlos Cristo diz textualmente: "Não acredito em livre mercado na aviação". Fundamenta esse ponto de vista, baseado na desigualdade do tamanho das empresas aéreas, o que dá margem para o "dumping". Todavia, a maior parte dos questionários dirige as respostas para a livre concorrência do mercado.

Na segunda etapa da pesquisa de campo, foi realizada uma entrevista, do tipo estruturada, com o Tenente Brigadeiro Marcos Sfoggia, realizada no primeiro trimestre de 2005. Para essa entrevista, foram utilizadas as seguintes questões:

1- Hoje não existe mais transporte aéreo regional? Qual a razão?

2- Na década de 70, tínhamos cinco empresas aéreas regionais que atendiam as cidades com menores populações. Quando passaram a ter âmbito nacional, deixaram de atendê-las. Se voltasse aquele sistema, há possibilidade de atendimento desse mercado?

3- O SITAR ajudou no crescimento da Embraer e no desenvolvimento da indústria da aviação brasileira?

4- Com o lançamento das aeronaves da Embraer de 70 a 110 assentos, há perspectiva de atendimento no âmbito regional?

5- Qual sua opinião sobre o transporte aéreo regional para o desenvolvimento do interior do país?

6- Com o Programa Nacional do Turismo, tendo como meta a regionalização, há possibilidade de uma parceria com a Aeronáutica no desenvolvimento dessas rotas?

7- Há planos da Aeronáutica para a criação de um novo SITAR?

8- Em sua opinião, o transporte aéreo regional deve ter uma reserva de mercado, contra o "gigantismo" das empresas de âmbito nacional? 
9- Qual o papel da aviação geral nesse contexto?

10- Mais algum comentário a respeito do transporte aéreo regional?

Analisando as respostas dadas pelo Brigadeiro Sfoggia, conforme pode ser visto no Anexo II, entende-se o transporte aéreo como um setor da economia mundial especialmente complexo, principalmente no Brasil, pelas características geográficas do país com largas distâncias entre os núcleos habitacionais, tendo muitas cidades com população de baixa renda e pouca demanda para viajar de avião, e carência de outros meios de transporte, precisando ter uma estrutura aeroviária mais adequada e fortalecida institucionalmente e financeiramente.

A Aeronáutica, conforme fica claro na entrevista, está preparada para continuar sendo o órgão controlador do setor e, mesmo que se crie uma Agência Reguladora, os militares devem completar grande parte do quadro de funcionários dessa nova estrutura, por deterem todo o conhecimento e experiência necessária para o desempenho adequado dessas funções.

O Brigadeiro entende que diversos empresários já se aventuraram nesse negócio, com muitos insucessos e experiências que não se sustentaram ao longo do tempo. Diversas empresas aéreas foram criadas no Brasil e encerraram suas atividades deixando usuários sem o seu serviço. Essa é mais uma razão para que qualquer iniciativa para novos entrantes nesse setor, seja acompanhada e fiscalizada com bastante energia pela autoridade competente, para assegurar que os passageiros estejam sendo atendidos por uma empresa que leva em consideração a segurança da operação como sua mais importante missão e razão de ser e não corra o risco do simples desaparecimento da empresa. Essa é a principal preocupação da Aeronáutica. Ele cita em uma das respostas: "A Aeronáutica ... produziu uma política para o transporte aéreo comercial que, bem ou mal, orientou o setor até o início da propalada desregulamentação que, a meu ver, precipitou a crise."

A citada desregulamentação ocorreu no início dos anos 90, quando houve forte pressão do Governo para que o DAC tomasse medidas liberatórias para a aviação comercial. 


\section{Considerações finais}

Um dos pontos mais importantes a considerar é que o turismo é atualmente a segunda maior indústria no mundo, e até o final do século será provavelmente a maior fonte mundial de empregos.

Portanto viajar faz bem para o espírito de quem viaja e para a receita do país visitado. E o Brasil, diante das peculiaridades que tem, é um grande convite a uma aventura diferente, e é isto que temos que explorar.

O planejamento integrado do transporte aéreo com outros modais também se apresenta como condição fundamental para garantir a qualidade no atendimento ao usuário e uma maior mobilidade na circulação de mercadorias e indivíduos.

O Sistema de Aviação Civil, como segmento do Poder Aeroespacial, participa do desenvolvimento nacional, num processo essencialmente dinâmico, com repercussões nos âmbitos nacional e internacional. A presença constante de brasileiros nos Organismos Internacionais da aviação faz parte deste processo e garante uma posição de destaque da Aviação Civil Brasileira no cenário mundial.

A qualidade, a produtividade e a preservação ambiental são exigências do processo de globalização por que passam todas as economias do mundo, tornando incontinenti o acompanhamento, em tempo real, da evolução tecnológica, para atualizar e adequar o Sistema de Aviação Civil brasileiro às tendências internacionais.

Os Recursos Humanos, a Infra-estrutura Aeronáutica e os Serviços Aéreos, que são os componentes funcionais do sistema, necessitam ter sua capacitação neste processo avaliada constantemente, visando à adequação das Diretrizes, Ações Estratégicas, Programas, Projetos e Atividades em curso.

Com esse propósito, faz-se necessário constante acompanhamento da evolução tecnológica da aviação civil e do desenvolvimento sócio-econômico do País. Se aceitarmos o fato de que nossa economia e sociedade continuarão a crescer como parte da economia global, é imperioso planejar para o atendimento da evolução das necessidades da aviação civil nacional e internacional. 
Os níveis de atividade do transporte aéreo refletem diretamente a atividade dos ciclos de negócios do mundo globalizado e respondem de forma quase imediata às políticas conjunturais. Em verdade, há amplo reconhecimento de que a importância do transporte aéreo para a vida moderna é muito maior do que o que pode fazer supor seu desempenho financeiro.

Com efeito, em que pese as grandes transformações pelas quais o setor passou na última década, parte da população brasileira se ressente desse modal, principalmente aquela das cidades de pequeno e médio porte, fora das capitais dos Estados. A rigor, de forma ainda tímida, o transporte aéreo vem crescendo em importância na matriz brasileira de transportes representando, por seus atributos, uma opção cada vez mais relevante na escolha de pessoas e empresas por esse meio de transporte. Isto sem mencionar sua importância para a integração nacional, neste país continente que tem 8,5 milhões de quilômetros quadrados, fator estratégico para um país com sérios problemas de acessibilidade.

As chamadas empresas aéreas regionais brasileiras planejam crescer $25 \%$ este ano, de acordo com reportagem do jornal Valor, edição de 19 de janeiro de 2005, pág. B3. Na mesma matéria consta: "Governo cria tarifa para subsidiar vôo de curta distancia". Essa participação do Governo é que deve ser estimulada e até exigida. De acordo com a IATA (Associação Internacional do Transporte Aéreo), a aviação global teve US\$ 35 bilhões de prejuízos entre 2000 e 2004. Não há atividade da economia que possa sobreviver dessa forma sem o amparo e proteção governamental.

Será esse pensamento o correto, tendo em vista a experiência dos anos passados? Será que o aprendizado apreendido não pode servir de guia mestre? Será que a experiência e a observação do que acontece no resto do mundo não pode nos orientar para evitarmos os erros do passado e os erros de algumas das nações desenvolvidas? Talvez o transporte aéreo no Brasil precise ter atenção especial das autoridades, com proteção do capital e do empresário nacional, diante das empresas internacionais. Deve-se resgatar o aprendizado da segunda metade da década de 70. Vamos estimular a indústria de construção de aeronaves para o mercado brasileiro, vamos encontrar formas de financiamento local, com recursos nacionais e 
fazer crescer o deslocamento interno, a utilização dos nossos hotéis e pousadas, vamos fazer girar essa roda da economia voltada para o turismo interno.

Sabe-se que o transporte aéreo, na década de 60, atendia mais de 400 cidades brasileiras por linhas aéreas regulares, contribuindo expressivamente para o desenvolvimento do interior do país. Hoje, pouco mais de 100 cidades brasileiras são atendidas. Destaca-se a importância da aviação civil para o desenvolvimento social e econômico do país e ainda mais seu papel estratégico desempenhado pela integração do território nacional

O Excelentíssimo Ministro da Defesa, Sr. José Viegas Filho, no dia 04 de março de 2004, no Hotel Nacional de Brasília, proferiu um discurso, durante os trabalhos do $2^{\circ}$ CONAR - CONGRESSO NACIONAL DE AVIAÇÃO REGIONAL, conforme pode ser visto no Anexo III.

O programa citado nesse discurso, permanece nos gabinetes do Poder Executivo, à espera de "melhor momento político" para ser implantado. Na realidade, além de ter que ser aceito pelo atual Ministro de Estado da Defesa e Vice-presidente da República, Sr. José Alencar, deve agradar ao Ministro Chefe da Casa Civil, ao Ministro de Estado da Fazenda, ao Ministro de Estado do Desenvolvimento, da Indústria e do Comércio Exterior, que são os ministros membros do Conselho Nacional de Aviação Civil. Portanto, tem que ser tomada uma atitude de Governo para retirar esse projeto "da gaveta".

Por fim, um pensamento elaborado por autor desconhecido, sintetisa o espírito que se queria demonstrar neste trabalho:

"Um homem precisa viajar...

Por sua conta, não por meio de histórias, imagens, livros ou TV.

Precisa viajar por si, com seus olhos e pés, para entender o que é seu.

Para um dia plantar as suas próprias árvores e dar-lhes valor.

Conhecer o frio, para desfrutar o calor e o oposto.

Sentir a distância e a alegria de retornar, ansiando a chegada do dia que poderá lá voltar. 
Um homem precisa viajar para lugares que não conhece, para quebrar essa arrogância que nos faz ver o mundo como imaginamos, e não simplesmente como é ou pode ser.

Que nos faz professores e doutores do que não vimos, quando deveríamos ser alunos, e simplesmente ir e ver".

(Autor desconhecido).

$$
+t+t
$$




\section{Bibliografia Consultada}

ASTI VERA, Armando. Metodologia da Pesquisa Cientifica. Porto Alegre: Ed. Globo, 1978.

BARRETTO, Margarita. Planejamento e organização em turismo. $6^{\mathrm{a}}$. ed. Campinas: Papirus, 2001.

BIGNAMI, R. A imagem do Brasil no turismo: construção, desafios e vantagem competitiva. São Paulo: Aleph, 2002.

CÂMARA DOS DEPUTADOS - Comissão de Turismo e Desporto. Anais do V Congresso Brasileiro da Atividade Turística - CBRATUR. I Seminário Internacional de Turismo e Desenvolvimento. Brasília, 25 e 26 de novembro, 2003.

CAVES, Richard E. Air Transport and its Regulations. Cambridge - MassachussetsUSA: Ed. Harvard University Press, 1968.

CORRÊA, Lu e BORBA, Ju. Registros do $2^{\circ}$. CONAR - Congresso Brasileiro de Aviação Regional. Brasília: Nettpress Assessoria de Imprensa, 04 de março, 2004.

DE MASI, Domenico. A Economia do Ócio / Paul Lafargue e Bertrand Russell / Organização e Introdução. Rio de Janeiro: Sextante, 2001.

DIAS, Reinaldo. Fundamentos de Sociologia Geral. 2a . ed. Campinas: Editora Alínea, 2000.

DIAS, Reinaldo e AGUIAR, Mariana Rodrigues. Fundamentos do Turismo. Campinas: Editora Alínea, 2002.

DIAS, Reinaldo. Planejamento do turismo: política e desenvolvimento do turismo no Brasil. São Paulo: Atlas, 2003.

DI RONÁ, Ronaldo. Transportes e Turismo. São Paulo: Editora Manole, 2002. FERRARI, Alfonso Trujillo. Metodología da Pesquisa Científica. São Paulo: Ed. Mcgraw-Hill do Brasil, 1982. 
KRIPPENDORF, Jost. Sociologia do Turismo - Para uma compreensão do lazer e das viagens. Rio de Janeiro: Civilização Brasileira, 1989.

LEI No. 7.565, de 19 de dezembro de 1986. Código Brasileiro de Aeronáutica - CBA.

LEMOS, Sandra Ferrapontoff. Transporte Aéreo e Turismo - Relato do $52^{\circ}$.

Congresso da AIEST (Association Internacionale d'Experts Scientifiques du

Tourisme. Salvador: 18 a 23 de agosto, 2002.

MINISTÉRIO DA AERONÁUTICA - Departamento de Aviação Civil. Política para os Serviços de Transporte Aéreo Comercial no Brasil. Brasília, 1992.

MINISTÉRIO DO TURISMO. Registros e anotações feitos no Fórum Mundial de Turismo para Paz e Desenvolvimento Sustentável. Salvador: dezembro, 2004.

MONTORO, Tânia Siqueira. Cultura do Turismo - Desafios e práticas Sócioambientais.

NASCIMENTO, João Alcides do. O Grande Comandante. Brasília: Ed. do Autor, 2004.

OLIVEIRA, Waldyr Viegas de. Orientação aos alunos na redação e apresentação. Brasília: Universidade de Brasília, 1995.

PALHARES, Guilherme L. Transporte Aéreo e Turismo - Gerando desenvolvimento sócio-econômico. São Paulo: Ed.Aleph, 2001.

REJOWSKI, Mirian. Turismo e Pesquisa Científica. São Paulo: Ed. Papirus, $3^{\mathrm{a}}$. Edição, 1999.

REVISTA Flap Internacional. Edições abril, 2004, pág. 28; setembro, 2004, pág. 30 e fevereiro, 2005, pág. 66.

REVISTA Foco Economia e Negócios. Edição 28 de fevereiro, 2005, pág. 22.

RUSCHMANN, Doris. Turismo e Planejamento Sustentável. $6^{a}$. Ed. Campinas: Ed. Papirus, 2003.

SHETH, Jagdish; MITTAL, Banwari e NEWMAN, Bruce. Comportamento do Cliente - Indo além do Comportamento do Consumidor. São Paulo: Atlas, 2001. 
SÍTIO da Infraero: www.infraero.gov.br

SÍTIO do Comando da Aeronáutica: www.fab.mil.br

SíTIO do Departamento de Aviação Civil: www.dac.gov.br

SÍTIO do Ministério da Defesa: www.defesa.gov.br

SÍTIO do Ministério do Turismo: www.turismo.gov.br

STANFORD RESEARCH INSTITUTE. El Transport Aéreo en La America Latina: Su

Desarrollo y Coordinación. Departamento de Asuntos Econômicos - Unión Panamericana, Washington DC: 1962. 
1- Você entende que o transporte aéreo contribui para o desenvolvimento do turismo no Brasil? Por quê?

R- A mobilidade é básica para o negócio do turismo: preços, horários, freqüências, destinos são variáveis determinantes da escolha de lugares para lazer e/ou reuniões de trabalho.

2- Sabendo-se que, em 1990, o Brasil detinha 65\% do tráfego aéreo entre o Brasil e os EUA e, após a liberação efetuada pelo Governo Collor, permitindo que mais empresas norte-americanas voassem para o Brasil, ficamos hoje com menos de 35\% desse mercado, permitindo que houvesse redução na entrada de divisas no país da ordem de quase USD 1 bilhão. Você é a favor de liberar o transporte aéreo para empresas estrangeiras ou entende que o governo deve controlar essa demanda?

R- Acredito em relações paritárias com salvaguardas, ou seja: que as companhias estejam em condições semelhantes na rota, inclusive com custos idênticos. Vetaria a prática de dumping. Não acredito em livre mercado na aviação.

3- Você entende que o transporte aéreo no Brasil devia seguir o modelo europeu, sendo propriedade do Estado, ou devia seguir o modelo americano, sendo propriedade privada?

R- Inclino-me ao modelo europeu, mas talvez se consiga algo entre um e outro, ou seja, mercado regulado.

4- Sabendo-se que mesmo nos EUA, não é permitido que estrangeiros sejam proprietários de empresas aéreas, você aceita o percentual de 20\% (limite de participação estrangeira nas empresas aéreas brasileiras), ou gostaria de propor outro percentual?

R- Parece-me que o problema fundamental é a possibilidade de se adquirir o controle com apenas $20 \% \ldots . . .$. e isto não me parece adequado. 
Carlos Manuel Pedroso Neves Cristo

Chefe de Gabinete do

Secretário de Tecnologia Industrial do

Ministério do Desenvolvimento, Indústria e Comércio Exterior

1- Você entende que o transporte aéreo contribui para o desenvolvimento do turismo no Brasil? Por quê?

R- Se não existissem as companhias aéreas não haveria turismo no Brasil. Num país com dimensões continentais, de que forma poderia ser dinamizado o turismo? Pena que só existam, no momento, três companhias de aviação. E que são poucas para atender a demanda. Se não existisse o transporte aéreo, seria tarefa árdua a de um gaúcho conhecer as maravilhosas praias nordestinas, ou melhor, dizendo, uma viagem terrestre penosa e cansativa.

2- Sabendo-se que, em 1990, o Brasil detinha 65\% do tráfego aéreo entre o Brasil e os EUA e, após a liberação efetuada pelo Governo Collor, permitindo que mais empresas norte-americanas voassem para o Brasil, ficamos hoje com menos de 35\% desse mercado, permitindo que houvesse redução na entrada de divisas no país da ordem de quase USD 1 bilhão. Você é a favor de liberar o transporte aéreo para empresas estrangeiras ou entende que o governo deve controlar essa demanda?

R- O Governo deve controlar o transporte aéreo estrangeiro. Penso, que a maneira que vem sendo feito, é bom. Uma linha deles e uma nossa. Uma divisão equânime.

3- Você entende que o transporte aéreo no Brasil devia seguir o modelo europeu, sendo propriedade do estado, ou deveria seguir o modelo americano, sendo propriedade privada?

R- Seria melhor que fosse propriedade privada, mas com o apoio do Governo, como sempre foi, antigamente. O que não se entende é que as companhias aéreas mundiais, com algumas exceções, voam lotadas e dão prejuízo. O Brasil é um exemplo. Alguma coisa está errada.

4- Sabendo-se que mesmo nos EUA, não é permitido que estrangeiros sejam proprietários de empresas aéreas, você aceita o percentual de 20\% (limite de 
participação estrangeira nas empresas aéreas brasileiras), ou gostaria de propor outro percentual?

R- Nada a opor a participação estrangeira nas empresas aéreas. Quanto ao limite de $20 \%$, sou favorável que seja maior, não maior do que $49 \%$.

\section{Gilberto Amaral}

Jornalista do Jornal do Brasil e do Jornal de Brasília

1- Você entende que o transporte aéreo contribui para o desenvolvimento do turismo no Brasil? Por quê?

R- Com toda a certeza. Pela insipiente infra-estrutura apresentada pela malha rodoviária e ferroviária no Brasil, a única opção que resta aos "pobres turistas" é o transporte aéreo. Infelizmente, o exorbitante preço das passagens aliado a um ineficiente atendimento aos clientes, faz com que o turismo aéreo nacional sobreviva de uma forma tímida, valendo-se tão somente de promoções e agendamento de pacotes.

2- Sabendo-se que, em 1990, o Brasil detinha 65\% do tráfego aéreo entre o Brasil e os EUA e, após a liberação efetuada pelo Governo Collor, permitindo que mais empresas norte-americanas voassem para o Brasil, ficamos hoje com menos de 35\% desse mercado, permitindo que houvesse redução na entrada de divisas no país da ordem de quase USD 1 bilhão. Você é a favor de liberar o transporte aéreo para empresas estrangeiras ou entende que o governo deve controlar essa demanda?

R- Sou a favor da livre concorrência entre as empresas, objetivando sempre minimizar os custos do usuário final. Em uma área tão especializada quanto o transporte aéreo, que envolve custos altíssimos em investimentos tecnológicos, manutenções planejadas, seguros, insumos básicos, treinamento de pessoal, etc., é de fundamental importância a máxima "quem não tem competência não se estabelece", pois sobretudo, a vida humana está em jogo. Porém, entendo que o governo deva em parte controlar as ações, criando uma Agência Regulatória que fiscalize o mercado da aviação civil brasileira. 
3- Você entende que o transporte aéreo no Brasil devia seguir o modelo europeu, sendo propriedade do Estado, ou devia seguir o modelo americano, sendo propriedade privada?

R- Acredito que o Estado não é excelente gestor em nenhuma atividade em que participa, portanto entendo que o transporte aéreo no Brasil deva ser de propriedade privada.

4- Sabendo-se que mesmo nos EUA, não é permitido que estrangeiros sejam proprietários de empresas aéreas, você aceita o percentual de 20\% (limite de participação estrangeira nas empresas aéreas brasileiras), ou gostaria de propor outro percentual?

R- Acho que qualquer percentual estabelecido para a participação estrangeira nas empresas aéreas brasileiras seria manipulado pelos proprietários, conforme seus interesses.

Gilson Machado - Engenheiro da Eletronorte

1- Você entende que o transporte aéreo contribui para o desenvolvimento do turismo no Brasil? Por quê?

R- Sim, tanto para o turismo interno, tendo presente as dimensões continentais do país, quanto para o turismo externo (receptivo).

2- Sabendo-se que, em 1990, o Brasil detinha 65\% do tráfego aéreo entre o Brasil e os EUA e, após a liberação efetuada pelo Governo Collor, permitindo que mais empresas norte-americanas voassem para o Brasil, ficamos hoje com menos de 35\% desse mercado, permitindo que houvesse redução na entrada de divisas no país da ordem de quase USD 1 bilhão. Você é a favor de liberar o transporte aéreo para empresas estrangeiras ou entende que o governo deve controlar essa demanda?

R- A pergunta deixa uma dúvida quanto ao segmento de transporte aéreo em causa, se o doméstico ou o internacional. No caso do transporte aéreo doméstico brasileiro minha opinião é que o mesmo deve ser explorado, exclusivamente, por empresas aéreas brasileiras; no caso do transporte aéreo internacional, o mesmo deve ser explorado, preferencialmente, por empresas de nacionalidade dos 
países nos quais se originam os tráfegos ou aos quais os mesmos se destinam, em regime de reciprocidade, ou seja, com igualdade de freqüência ou freqüências na rota. Todavia, se a empresa ou as empresas de um dos países signatários não atingem, qualquer que seja o motivo, performance que assegure a efetividade do princípio da reciprocidade em regime de competição, então o Governo daquele país deve intervir, adotando providências que impliquem não em penalizações para as empresas estrangeiras, mas em fortalecimento das empresas nacionais, inclusive, se for o caso, substituindo-as quando não competitivas.

3- Você entende que o transporte aéreo no Brasil devia seguir o modelo europeu, sendo propriedade do Estado, ou devia seguir o modelo americano, sendo propriedade privada?

R- Sugiro que a pergunta seja reformulada, primeiro porque não é possível, por definição, exercer direito de propriedade sobre "atividades", quaisquer que sejam elas; em segundo porque é necessário esclarecer de que modalidade de transporte aéreo se trata. No caso, parece que parece que o que se pretende indagar é se a exploração de terminada atividade, no caso o transporte aéreo, deve ser realizada diretamente pelo Estado ou por uma empresa estatal ( delegatária ) em regime de monopólio ou, alternativamente, por uma empresa privada, mediante concessão, permissão ou autorização do Poder Público competente, visto tratar-se, no caso, de atividade (transporte aéreo) que consubstancia inafastável interesse público. Assim entendida a questão, minha opinião é de que a exploração da atividade de transporte aéreo, qualquer que seja a sua modalidade (serviços aéreos especializados públicos ou serviços de transporte aéreo público de passageiros, carga e mala postal, regular ou nãoregular, doméstico ou internacional) deve ser explorada pelo setor privado, em regime de livre concorrência, sem prejuízo da fiscalização e da regulação pelo Poder Público, admitindo-se, portanto, intervenções estatais para corrigir as imperfeições do mercado, sempre que essas ocorrerem.

4- Sabendo-se que mesmo nos EUA, não é permitido que estrangeiros sejam proprietários de empresas aéreas, você aceita o percentual de 20\% (limite de 
participação estrangeira nas empresas aéreas brasileiras), ou gostaria de propor outro percentual?

R- Minha opinião é de que devemos manter, no Brasil, o percentual hoje estabelecido no CBA, ou seja, um limite máximo de 20\% (ou 1/5) para participação de estrangeiros no capital de empresas aéreas brasileiras, direta ou indiretamente.

Geraldo Ribeiro Vieira

Advogado do Sindicato Nacional das Empresas Aeroviárias - SNEA

1- Você entende que o transporte aéreo contribui para o desenvolvimento do turismo no Brasil? Por quê?

R- Sim. Sob o ponto de vista externo, porque as chegadas marítimas são insuficientes para a procura (demanda), e as chegadas terrestres são insignificantes. Como o turismo originário no exterior ainda tem muita coisa que pode ser explorada, o aumento quantitativo e qualitativo do tráfego aéreo deverá poder implicar um aumento dos fluxos turísticos. Dito isto, há factores negativos para a imagem do país, sendo exemplos: a destruição das florestas tropicais e das matas atlânticas; a sobre-exploração de certas áreas, como Angra dos Reis, que com o tempo irão fazer diminuir ou mesmo extinguir os fluxos turísticos de média-alta e alta qualidade; a insegurança e o crime. A valorização do real, se se mantiver, não favorecerá o turismo para o Brasil.

Do ponto vista interno, a resposta parece óbvia, mas não tenho dados para uma resposta rápida. Todavia, dado que as estradas estão num estado deplorável e não há caminhos de ferro nem transportes turísticos fluviais, e os meios marítimos são muito insuficientes, só há turismo interno se houver transportes aéreos.

2- Sabendo-se que, em 1990, o Brasil detinha 65\% do tráfego aéreo entre o Brasil e os EUA e, após a liberação efetuada pelo Governo Collor, permitindo que mais empresas norte-americanas voassem para o Brasil, ficamos hoje com menos de 35\% desse mercado, permitindo que houvesse redução na entrada de divisas no país da ordem de quase USD 1 bilhão. Você é a favor 
de liberar o transporte aéreo para empresas estrangeiras ou entende que o governo deve controlar essa demanda?

R- A liberalização é uma estrada com duas mãos. Deve-se liberalizar o tráfego aéreo para empresas estrangeiras e negociar facilidades semelhantes para empresas brasileiras. Controlar, ou reduzir, ou pôr fim à concorrência externa, significará, a prazo, pôr os aviões brasileiros a voar só no Brasil. Tal não parece possível, o jogo de fluxos implica acordos aéreos mutuamente proveitosos, um acordo só é bom a prazo se for vantajoso para ambas as partes.

3- Você entende que o transporte aéreo no Brasil devia seguir o modelo europeu, sendo propriedade do Estado, ou devia seguir o modelo americano, sendo propriedade privada?

R- Que eu saiba, não há um modelo europeu em que o transporte aéreo seja do Estado. Por outro lado, os problemas do transporte aéreo, sobretudo de companhias aéreas - as empresas de gestão de aeroportos, e outras, não seguem necessariamente o mesmo padrão - não se restringem a um tipo ou outro de propriedade, mas têm a ver com a qualidade da gestão, do endividamento das empresas e do tipo de serviços oferecidos, para mencionar apenas os que me parecem mais importantes em termos gerais.

4- Sabendo-se que mesmo nos EUA, não é permitido que estrangeiros sejam proprietários de empresas aéreas, você aceita o percentual de 20\% (limite de participação estrangeira nas empresas aéreas brasileiras), ou gostaria de propor outro percentual?

R- Não tenho dados suficientes para me pronunciar, mesmo de uma forma superficial. Talvez que a resposta nem deva mesmo ser superficial. Apenas acrescento pois que esse tipo de percentagens é definido politicamente, não tem nada a ver com a gestão. A gestão não é boa ou má porque os estrangeiros têm mais ou menos de $20 \%$.

João Gabriel Matos Ferreira

Primeiro Conselheiro da Delegação da Comunidade Européia no Brasil 
1- Você entende que o transporte aéreo contribui para o desenvolvimento do turismo no Brasil? Por quê?

R- Todas as formas de locomoção pública colaboram para que o turismo se expanda. A aviação, sendo ainda a maneira mais rápida de se chegar a qualquer destino destaca-se particularmente pelo aumento de linhas e rotas. Com isto, o turista dispõe de mais opções tornando suas viagens bem mais convenientes, seguras e confortáveis. Sem sombra de dúvida poder contar com o transporte aéreo é fator de tranqüilidade e confiança para a sociedade como um todo.

2- Sabendo-se que, em 1990, o Brasil detinha $65 \%$ do tráfego aéreo entre o Brasil e os EUA e, após a liberação efetuada pelo Governo Collor, permitindo que mais empresas norte-americanas voassem para o Brasil, ficamos hoje com menos de $35 \%$ desse mercado, permitindo que houvesse redução na entrada de divisas no país da ordem de quase USD 1 bilhão. Você é a favor de liberar o transporte aéreo para empresas estrangeiras ou entende que o governo deve controlar essa demanda?

R- Na minha opinião o governo deveria intervir nesta questão assim como os governos de outros países o fazem, no sentido de proteger o mercado interno.

Favorecer a entrada de mercados estrangeiros no ramo da aviação no Brasil sem o menor controle significa indiretamente liquidar com as empresas nacionais, que por anos vieram atendendo com esmero à demanda da nossa população.

3- Você entende que o transporte aéreo no Brasil devia seguir o modelo europeu, sendo propriedade do Estado, ou devia seguir o modelo americano, sendo propriedade privada?

R- Penso que as empresas de aviação, sendo elas de propriedade estatal ou privada devem acima de tudo operar dentro da realidade do poder aquisitivo da população, oferecendo serviços diversificados que atendam às demandas de diferentes camadas da sociedade.

4- Sabendo-se que mesmo nos EUA, não é permitido que estrangeiros sejam proprietários de empresas aéreas, você aceita o percentual de 20\% (limite de 
participação estrangeira nas empresas aéreas brasileiras), ou gostaria de propor outro percentual?

R- Poderíamos propor outro percentual ou ainda, tentar negociar com os americanos para que abrissem espaço para a entrada de empresas estrangeiras em seu país. Como a segunda alternativa parece por hora inviável dada intransigência da economia americana, poderíamos re-pensar um percentual para a participação estrangeira no Brasil, DESDE que esta suposta reserva de mercado não venha em detrimento dos serviços e da qualidade já oferecida à população brasileira com o advento da entrada no mercado empresas estrangeiras.

Laura da Silva Prado Ferrari

Tradutora, Intérprete e Empresária

1- Você entende que o transporte aéreo contribui para o desenvolvimento do turismo no Brasil? Por quê?

R- Sim. Devido às longas distâncias entre os diferentes pontos turísticos, ao precário estado de conservação de algumas rodovias e por último ao fato dos riscos de viagens rodoviárias em período noturno, o transporte aéreo permite as deslocações quer de turistas nacionais quer estrangeiros. O trem, de preferência estilo "trem bala" seria uma boa alternativa ou complemento ao transporte aéreo como forma de promoção do turismo no Brasil.

2- Sabendo-se que, em 1990, o Brasil detinha 65\% do tráfego aéreo entre o Brasil e os EUA e, após a liberação efetuada pelo Governo Collor, permitindo que mais empresas norte-americanas voassem para o Brasil, ficamos hoje com menos de 35\% desse mercado, permitindo que houvesse redução na entrada de divisas no país da ordem de quase USD 1 bilhão. Você é a favor de liberar o transporte aéreo para empresas estrangeiras ou entende que o governo deve controlar essa demanda?

R- Na perspectiva do consumidor a liberação do trafego aéreo a abertura do mercado é vantajosa. Numa situação de livre concorrência as empresas serão obrigadas a melhorar a sua forma de gestão, reduzindo custos de ineficiência de 
forma aos seus preços serem competitivos. O consumidor pagará menos por um serviço equivalente.

3- Você entende que o transporte aéreo no Brasil devia seguir o modelo europeu, sendo propriedade do Estado, ou devia seguir o modelo americano, sendo propriedade privada?

R- Acredito que nem em todos os paises europeus a intervenção do estado, nas companhias aéreas, seja totalitária. Regra geral há uma companhia nacional, talvez a maior, com capital (talvez maioritário) do estado. Mas há companhia de capital exclusivamente privado, como por exemplo a Portugália em Portugal e, se não me engano, a SN (que substitui o espaço da Sabena) já não tem capital público. No reino Unido temos a Virgin, na Irlanda a Raianair, que têm uma cota de mercado não despresivel. Mas retomando a pergunta, a intervenção do estado não deve ser maioritária e muito menos exclusiva. O estado não tem vocação para gestor comercial. O papel do estado deve ser garante da boa aplicação das regras de concorrência, de segurança, alguma intervenção social, por exemplo, distribuição de subsídios para desenvolvimento das atividades em regiões mais carênciadas, etc. Uma participação no capital das empresas aéreas pode ser benéfico facilitando o conhecimento das práticas das empresas, mas a participação no capital pode ser minoritária.

4- Sabendo-se que mesmo nos EUA, não é permitido que estrangeiros sejam proprietários de empresas aéreas, você aceita o percentual de 20\% (limite de participação estrangeira nas empresas aéreas brasileiras), ou gostaria de propor outro percentual?

R- O conceito de investimento estrangeiro tem uma aceitação diferente para um europeu comunitário (como é o meu caso) que terá para um brasileiro ou para um americano. Na Europa hoje o conceito de investimento estrangeiro tem cada vez menos relevância porque estamos num espaço comercial aberto entre os 25 da União Européia. Para o Brasil o conceito de investimento deveria ter um "nuance" de estrangeiro do Mercosul ou fora do Mercosul. A abertura ao investimento estrangeiro, ou a sua participação dominante pode lesar os interesses nacionais. Ninguém dá nada a ninguém e ainda menos quando o investimento é estrangeiro, porque ele tem menos preocupações sociais e 
sobre os efeitos ambientais da sua atividade. Um percentual diminuto de investimento estrangeiro conduz a uma retração do interesse no negócio. Uma empresa estrangeira precisa de garantias de sucessos no investimento. Se a sua participação de capital for muito baixa os riscos de insucesso serão maiores. Há setores de atividade que, questões de interesse nacional não podem ficar sob controlo estrangeiro. Mas o transporte aéreo não deveria estar nessa categoria. Um percentual de $20 \%$ pode ser suficiente, em casos de disseminação do capital, para controlar a empresa. Ser 20, 30 ou 40 \% pode não ter diferença para a questão. Abaixo de 20 \% não deverá ser atraente para o estrangeiro e a cima de 50 \% pode ser perturbador, para o mercado de trabalhado, em situações de encerramento repentino da atividade.

Amador Militão - Conselheiro Econômico da Delegação da Comunidade Européia no Brasil

1- Você entende que o transporte aéreo contribui para o desenvolvimento do turismo no Brasil? Por quê?

R- Claro que sim. Porque sem avião não poderíamos conhecer os lugares mais distantes encravados em determinadas regiões, no curto espaço de tempo disponível, por exemplo, mas existem outras inúmeras razões.

2- Sabendo-se que, em 1990, o Brasil detinha 65\% do tráfego aéreo entre o Brasil e os EUA e, após a liberação efetuada pelo Governo Collor, permitindo que mais empresas norte-americanas voassem para o Brasil, ficamos hoje com menos de 35\% desse mercado, permitindo que houvesse redução na entrada de divisas no país da ordem de quase USD 1 bilhão. Você é a favor de liberar o transporte aéreo para empresas estrangeiras ou entende que o governo deve controlar essa demanda?

R- Não sou a favor da liberação do transporte aéreo para empresas estrangeiras, mas não sou a favor de que o governo controle essa demanda. Entendo que deveria haver uma lei rigorosa de reciprocidade e as empresas aéreas brasileiras dominarem o tráfego aéreo do Brasil para o resto do mundo, e internamente também... 
3- Você entende que o transporte aéreo no Brasil devia seguir o modelo europeu, sendo propriedade do Estado, ou devia seguir o modelo americano, sendo propriedade privada?

R- Propriedade privada, mas não seguindo um modelo específico...O Brasil é diferente dos EUA.

4- Sabendo-se que mesmo nos EUA, não é permitido que estrangeiros sejam proprietários de empresas aéreas, você aceita o percentual de 20\% (limite de participação estrangeira nas empresas aéreas brasileiras), ou gostaria de propor outro percentual?

R- É indiferente a participação acionária, desde que as empresas brasileiras continuassem com a maioria do capital acionário.

\section{Paula Miranda}

Advogada, especialista em direito aeronáutico e empresária

1- Você entende que o transporte aéreo contribui para o desenvolvimento do turismo no Brasil? Por quê?

R- Sim. Basicamente em função das distâncias e do conforto. E, hoje, com as low fare e low cost, pela relação custo benefício.

2- Sabendo-se que, em 1990, o Brasil detinha 65\% do tráfego aéreo entre o Brasil e os EUA e, após a liberação efetuada pelo Governo Collor, permitindo que mais empresas norte-americanas voassem para o Brasil, ficamos hoje com menos de 35\% desse mercado, permitindo que houvesse redução na entrada de divisas no país da ordem de quase USD 1 bilhão. Você é a favor de liberar o transporte aéreo para empresas estrangeiras ou entende que o governo deve controlar essa demanda?

R- Deve haver sempre reciprocidade entre os paises. Mas quando a guerra é desigual, como entre EUA e Brasil - há que haver regras que estimulem nosso turismo, sem acobertar ineficiência e mã gestão das brasileiras. 
3- Você entende que o transporte aéreo no Brasil devia seguir o modelo europeu, sendo propriedade do Estado, ou devia seguir o modelo americano, sendo propriedade privada?

R- Aqui deve-se encontrar uma fórmula nossa, mas, em princípio, privada. Claro, sem que se entregue o controle a " personalidades" estranhas e desconhecedoras da aviação, como tivemos em alguns casos.

4- Sabendo-se que mesmo nos EUA, não é permitido que estrangeiros sejam proprietários de empresas aéreas, você aceita o percentual de 20\% (limite de participação estrangeira nas empresas aéreas brasileiras), ou gostaria de propor outro percentual?

R- Lá a situação é diferente (impostos menores etc), as empresas quebram. Mas em termos de percentual, não acredito que gere problemas, veja o pão de açúcar, ambev,. Infelizmente não temos economia de escala, portanto, precisamos proteger nossa economia sem gerar ineficiência. Em última instância, somos nós que pagamos a diferença. Mas de qualquer forma, precisamos melhorar o que já temos de bom, a gestão.

Thales Leite

ATA Palestras

1- Você entende que o transporte aéreo contribui para o desenvolvimento do turismo no Brasil? Por quê?

R-Sim, transporte rápido, eficiente e seguro.

2- Sabendo-se que, em 1990, o Brasil detinha 65\% do tráfego aéreo entre o Brasil e os EUA e, após a liberação efetuada pelo Governo Collor, permitindo que mais empresas norte-americanas voassem para o Brasil, ficamos hoje com menos de 35\% desse mercado, permitindo que houvesse redução na entrada de divisas no país da ordem de quase USD 1 bilhão. Você é a favor de liberar o transporte aéreo para empresas estrangeiras ou entende que o governo deve controlar essa demanda? 
R-Sou a favor da concorrência em qualquer setor, mesmo sendo com empresas estrangeiras. Mas só nos casos em que houver a reciprocidade dos outros paises.

3- Você entende que o transporte aéreo no Brasil devia seguir o modelo europeu, sendo propriedade do Estado, ou devia seguir o modelo americano, sendo propriedade privada?

R- Entendo que deve seguir o modelo Americano. Na minha opinião as empresas privadas são mais competitivas.

4- Sabendo-se que mesmo nos EUA, não é permitido que estrangeiros sejam proprietários de empresas aéreas, você aceita o percentual de 20\% (limite de participação estrangeira nas empresas aéreas brasileiras), ou gostaria de propor outro percentual?

R- No nosso caso, por sermos um pais pobre, acho razoável o porcentual de $20 \%$.

Antônio Carlos Luongo Sanchez

Empresário 
ANEXO III

Discurso proferido no $2^{\circ}$. CONAR - CONGRESSO NACIONAL DE AVIAÇÃO REGIONAL, pelo Excelentíssimo Ministro de Estado da Defesa, Sr. José Viegas Filho, em março/2004:

" ... Esta situação é decorrente de vários fatores, entre os quais podemos citar:

1- empresas voltadas apenas ao atendimento dos locais de alta densidade de passageiros;

2- deficiências na infra-estrutura dos aeródromos menores;

3- indisponibilidade de aeronaves adequadas às ligações de média e baixa densidade de passageiros;

4- falta de políticas públicas voltadas para transporte aéreo, em consonância com as necessidades do setor;

5- inadequações do marco regulatório à aviação regional; e

6- estrutura de preços de combustíveis inadequada à aviação regional.

O momento atual exige reflexão e compartilhamento de esforços, uma busca de compromissos e soluções duradouras para o transporte aéreo regional, o qual somente terá sua existência justificada pelo cumprimento da missão de integrar o país e ampliar o acesso para uma parcela da população que dele muito necessita. Se não houver atitudes e disposição positiva para enfrentar estes desafios, poderemos voltar ao quadro da década de 70, quando apenas 75 cidades eram servidas pelo transporte aéreo regular.

Limito o meu desafio a enfocarmos apenas algumas desta medidas que têm maior identidade com a aviação regional:

Financiamento em Reais - Programa de financiamento em reais de aeronaves produzidas no Brasil para empresas nacionais. 
Tributação - Revisão da legislação com o objetivo de desonerar todos os segmentos da aviação civil, assegurando a competividade do setor.

Combustível - Avaliação da adequação da política de preços, restrição da volatilidade dos preços do combustível e equacionamento dos problemas de distribuição.

Plano Aeroviário Nacional - Integração nacional, contemplando as orientações e prioridades de investimentos em aeródromos dos três níveis de governo e da iniciativa privada.

Linhas Aéreas Essenciais - Viabilização de recursos, por um prazo definido, para estimular linhas aéreas entre localidades de interesse estratégico, econômico ou turístico, onde não há sustentação econômica a curto e médio prazo.

Parceria Público-Privada - Aplicação deste instituto à realização dos investimentos em infra-estrutura aeroportuária dentro do Projeto Parceria Público-Privada.

Modelos de Gestão - Elaboração de um modelo para gestão da malha de aeródromos a ser desenvolvida. O modelo de gestão, aplicado ao aeródromo, enfoca um Plano de Desenvolvimento do Aeródromo, voltado para as potencialidades da localidade, onde sejam estabelecidas metas visando à sua auto-sustentação.

Particularmente nesta oportunidade, estamos disponibilizando aos organizadores deste Congresso um Anteprojeto elaborado especificamente para a aviação regional, denominado PROGRAMA DE DESENVOLVIMENTO DA AVIAÇÃO REGIONAL, que é parte integrante da Política de Aviação Civil, elaborado com base nas propostas apresentadas pelo Comitê Técnico de Políticas Públicas e nas diretrizes aprovadas pelo CONAC, como forma de contribuir para as discussões deste Congresso." 